九州大学学術情報リポジトリ

Kyushu University Institutional Repository

Comparison of Growth Feature and Drought Tolerance between Two High Productive Species, Kenaf (Hibicus cannabinus, C3-plant) and Napiergrass (Pennisetum purpureum, C4plant)

Nguyen, Mai Thi Phuong

Graduate School of Bioresource and Bioenvironmental Sciences, Kyushu University

Araki, Takuya

Faculty of Agriculture, Kyushu University

Kubota, Fumitake

Faculty of Agriculture, Kyushu University

https://doi.org/10.5109/4666

出版情報: 九州大学大学院農学研究院紀要. 50 (2)，pp.521-532，2005-10-01. Faculty of Agriculture, Kyushu University

バージョン：

権利関係 : 


\title{
Comparison of Growth Feature and Drought Tolerance between Two High Productive Species, Kenaf (Hibicus cannabinus, C3-plant) and Napiergrass (Pennisetum purpureum, C4-plant)
}

\author{
Mai Thi Phuong NGUYEN ${ }^{*}$, Takuya ARAKI \\ and Fumitake KUBOTA
}

\author{
Laboratory of Plant Production Physiology, Division of Soil Science and Plant Production, \\ Department of Plant Resources, Faculty of Agriculture, \\ Kyushu University, Fukuoka 812-8581, Japan \\ (Received June 28, 2005 and accepted July 26, 2005)
}

\begin{abstract}
Kenaf (Hibicus Cannabinus) and napiergrass (Pennisetum purpureum) are known as C3- and C4-plant species with a high biomass productivity and drought tolerance, respectively. Their growth features and photosynthetic responses to mild and severe drought treatments were investigated in pot cultivations. The results obtained were as follows: 1) The biomass production of kenaf was large, almost similar to that of napiergrass. The $\mathrm{CO}_{2}$ exchange rate (CER) and stomatal conductance (Gs) of kenaf were high and stable during the sunshine time, while those parameters of napiergrass had a decreasing tendency toward the afternoon. 2) CER, Gs and mesophyll conductance (Gm) in both species were depressed in the drought treatments. C4-plants are known to have a high tolerance to droughts, but here in kenaf, CER showed a less depression compared to that of napiergrass in the drought treatments, and by re-watering CER of kenaf was quickly recovered. On the other hand, Gm in napiergrass was more sensitive to the drought treatments and its recovery was incomplete. 3) The drought treatments did not strongly affected the maximum quantum yields in photosystem II (Fv/Fm) in both species, but had a significant effect on the quantum yield $(\Phi \mathrm{e})$ in the stable photosynthetic condition. The depression of $\Phi$ e was significantly larger in napiergrass, and its recovery by re-watering was poor. The high tolerability and quick recovery in kenaf is presumed to depend on photorespiration, by which the excessive energy in leaves was effectively dissipated to protect the photosynthetic apparatus.
\end{abstract}

\section{INTRODUCTION}

Kenaf (Hibicus cannabinus) is grown in the temperate and sub-tropical regions, and used as animal food, raw material for paper production and other industrial stuff. This species is known to show a high leaf-photosynthetic rate compared to that of other C3-plants (Lam et al., 2003). Yields of fresh biomass were reported to reach as much as 52.3 to $88.9 \mathrm{t} \mathrm{ha}^{-1}$, corresponding to a dry mass of 13.3 to $24.0 \mathrm{t} \mathrm{ha}^{-1}$ (Alexopoulou et al., 2000). Kenaf is possible to be introduced into semi-arid regions (Francois et al., 1992). In fact, the growth area of kenaf is gradually increasing in the dry-textured, marginal soils where water deficits frequently occur during the growth period.

Napiergrass (Pennisetum purpureum) is one of the C4-plants, grown in the area

\footnotetext{
1 Laboratory of Plant Production Physiology, Division of Soil Science and Plant Production, Graduate School of Bioresource and Bioenvironmental Sciences, Kyushu University

* Corresponding author (E-mail: ntphmai@agr.kyushu-u.ac.jp)
} 
from the temperate to tropical regions, and used for paper chip material and forage. Napiergrass is chosen as a species that performs a particularly large biomass production among C4-plants, recording more than $50 \mathrm{t} \mathrm{ha}^{-1}$ in dry matter (Watkin et al., 1951). This species is also adaptable to drought growth conditions (Nada et al., 1994; Nagasuga, 2003).

As mentioned, the growth of kenaf is characterized by a large biomass production and a high drought tolerance which are similarly observed in C4-plants. The authors have been interested in clarifying the specific characteristics of both species and understanding the production and drought tolerance mechanisms unique to kenaf. The information obtained would be useful for the increment and stabilization of production in many C3- and C4-crops.

At the first step, we observed the growth features of these species; then investigated the effects of droughts and re-watering on the photosynthetic production in this study. The adverse effect of water deficit on growth and photosynthesis in crops have been much studied until now, and in general, photosynthetic inhibition was observed as one of the primary and most obvious repercussions of water stress effect on plant metabolisms (Chaves, 1991; Raghavendra, 1998; Medrano et al., 2002). In many cases, stomatal closure occurred in water-stressed plants, leading to a decline in $\mathrm{CO}_{2}$ uptake and causing various impairments of metabolic functions.

The stomatal movement may have a close relationship with the intercellular $\mathrm{CO}_{2}$ concentration and gas exchange rate of leaves. The stomatal aperture also significantly affects the photorespiration rate in C3-plants, changing the energy flow in a leaf. The occurrence of unbalanced energy flow under drought conditions may frequently cause a serious physiological damage in leaves (Chaves, 1991; Cornic and Massacci, 1996; Wingler et al., 1999).

The materials used here have interesting and important features in growth and drought tolerance, but not so many studies have been found on the photosynthetic analysis of both species (Matsuda at el., 1991; Kubota et al., 1994; Ogbonnaya et al., 1998; Nagasuga, 2003). For the purpose of clarifying one of the important eco-physiological aspects in kenaf and napiergrass, we here placed the focus on their growth features and photosynthetic responses to droughts in both species, and discussed them from the view points of $\mathrm{CO}_{2}$ exchange rate (CER), stomatal action, photorespiration and photosystem II (PSII) energy transport.

\section{MATERIALS AND METHODS}

\section{Materials and Cultivation}

Kenaf (Hibicus cannabinus, C3-plant) and napiergrass (Pennisentum purpureum, C4-plant), were used as experimental materials. The pot cultivation of these species was conducted from July to August, 2004 in the experimental field of Kyushu University. Five seeds of kenaf were sown in a pot and germinated plants were thinned to one plant. When kenaf plants grew to about $5 \mathrm{~cm}$ in height, young shoots of napiergrass sprouted from plant stocks grown in the field were transplanted to pots. One plant of kenaf and one shoot of napiergrass were grown together in a 8-liter pot filled with sandy soil. In this cultivation, two species were grown under the same soil condition 
in a pot, so their growth can be accurately compared.

To eliminate the influence of nutrient deficits on growth, a sufficient amount of fertilizer ( $10 \mathrm{~g}$ of a compound chemical fertilizer with ratio of $\mathrm{N}: \mathrm{P}: \mathrm{K}=16: 16: 16$ ) was applied to each pot soil. As additional fertilization, $5 \mathrm{~g} /$ pot of nitrogen was top-dressed twice during the cultivation period. All the plants were grown under adequately watered conditions for 30 days before drought treatments were imposed.

\section{Treatments}

Pots with vigorous growth plants were divided into two groups. One group was subjected to drought treatments and used to analyze the photosynthetic responses to droughts. The other group was grown with adequate water supply and used as a control. Two drought levels, lenient and acute water-cut treatments, were imposed on both species grown together in a pot for 30 days. The lenient treatment (mild drought) was conducted through one week by gradually reducing water supply until the water potential of soil decreased to $-1.33 \mathrm{Mpa}$ on average. One the other hand, the acute treatment (severe drought) was imposed by complete restriction of water supply, by which the water potential of soil was decreased to $-2.51 \mathrm{MPa}$ within two days. Directly after the drought treatments, plants were re-watered for three days to recover their growth.

\section{Measurements}

Growth parameters

For analyses of the growth, three to five plants were sampled at one week interval during the $30^{\text {th }}$ to $56^{\text {th }}$ day. The plant parts, leaf, stem and root, were separated to measure fresh and dry matter weight, and leaf area. The leaf area of individual plants was measured with an automatic area meter (Model AAM 8, Hayashi Denko, Japan). Then the dried weight of each part was determined after 5-day oven drying at $80^{\circ} \mathrm{C}$. From the data obtained, leaf area per plant (LA), plant growth rate (PGR), net assimilation rate per plant (NAR) were calculated.

\section{Measurements of $\mathrm{CO}_{2}$ exchange rate (CER) and the related parameters.}

The intact fully expanded leaves were used for the photosynthetic measurement. CER, stomatal conductance (Gs) and mesophyll conductance (Gm) of leaves were simultaneously determined by using a sandwich-type assimilation chamber $\left(\mathrm{CO}_{2}-\mathrm{H}_{2} \mathrm{O}\right.$ analyzer Li 6262, Li-COR, USA). As measurement environments, a light intensity of $500 \mu \mathrm{mol} \mathrm{m}{ }^{-2}$ $\mathrm{s}^{-1} \mathrm{PPFD}$, leaf temperature of $30^{\circ} \mathrm{C}$ and air relative humidity of $60 \%$ were used. The leaf area enclosed in the assimilation chamber was $6.25 \mathrm{~cm}^{2}$ and the air flow rate through the chamber was adjusted at about $1 \mathrm{~L} \mathrm{~min}{ }^{-1}$. The diurnal changes in CER and Gs of both species were monitored in a sunshiny day by using a potable $\mathrm{CO}_{2}-\mathrm{H}_{2} \mathrm{O}$ analyzer (Lc PRO, $\mathrm{ADC}, \mathrm{UK})$.

\section{Determination of electron transport rate (ETR) and the related parameters}

Chlorophyll fluorescence of PSII was monitored with a fluorescence probe (PAM-2000, Walz, Germany) attached on the assimilation chamber. After dark-adaptation of leaves for at least 20 minutes, the minimal fluorescence (Fo) was measured with a

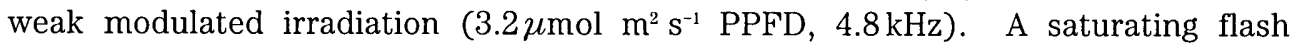


(1800 $\left.\mathrm{umolm}^{2} \mathrm{~s}^{-1} \mathrm{PPFD}\right)$ was applied on to a leaf to determine the maximum chlorophyll fluorescence $(\mathrm{Fm})$ and the maximum quantum yield [( $\mathrm{Fm}-\mathrm{Fo}) / \mathrm{Fm}$, or $\mathrm{Fv} / \mathrm{Fm}$ ].

After this, the time course of quenching of the fluorescence (Fs) was monitored at $500 \mu \mathrm{mol} \mathrm{m} \mathrm{m}^{2} \mathrm{~s}^{-1} \mathrm{PPFD}$, during which the fluorescence spike (F'm) was periodically measured by giving pulses of saturation light. ETR and PSII quantum yield $(\Phi e)$ were calculated from the following equations (1) and (2).

$$
\begin{aligned}
& \Phi \mathrm{e}=\left(F^{\prime} \mathrm{m}-\mathrm{Fs}\right) / \mathrm{F}^{\prime} \mathrm{m} \\
& \mathrm{ETR}=\Phi \mathrm{e} \cdot \mathrm{I} \cdot \mathrm{a} \cdot \mathrm{b}
\end{aligned}
$$

where I is light intensity ( $\mu \mathrm{mol} \mathrm{m} \mathrm{m}^{2} \mathrm{~s}^{-1} \mathrm{PPFD}$ ) supplied to a leaf, ' $\mathrm{a}$ ' is the ratio of photons actually absorbed by a leaf to the total incident photons irradiated to the leaf, and ' $\mathrm{b}$ ' is the ratio of photons divided to PSII to the total incident photons absorbed by a leaf. We used 0.8 (a measured value) for ' $a$ ', and 0.5 for ' $b$ ' according to the assumption that absorbed photons are distributed evenly into the two photosystems within a leaf.

Estimation of photorespiration rate (Pr) and non-photochemical quenching (NPQ)

$\mathrm{Pr}$ is given by subtracting the gross photosynthetic rate $(\mathrm{Pg})$ from the total $\mathrm{CO}_{2}$ fixation rate $(\mathrm{Tc})$ in a leaf

$$
\operatorname{Pr}=\mathrm{Tc}-\mathrm{Pg}
$$

The equation (3) is rewritten as the equation (4) on the basis of electron transport rate.

$$
\mathrm{ETR}=\mathrm{kc} \cdot \mathrm{Tc}+2.06 \cdot \mathrm{kc} \cdot \mathrm{Pr}
$$

where, $\mathrm{kc}$ is the number of electrons used for fixing $1 \mathrm{~mol} \mathrm{CO}_{2}$ in assimilation $(\mathrm{kc}=4)$, then $\mathrm{kc} \cdot \mathrm{Tc}$ is the number of electrons used for $\mathrm{CO}_{2}$ absorption in assimilation. The number of electrons required for releasing $1 \mathrm{~mol} \mathrm{CO}_{2}$ by photorespiration is $\mathrm{kr}$, and the value of $\mathrm{kr}$ is 2.06 times that of $\mathrm{kc}$ (Oliver, 1994). Therefore, $2.06 \cdot \mathrm{kc} \cdot \mathrm{Pr}$ indicates the electron transport rate used for releasing $1 \mathrm{~mol} \mathrm{CO}_{2}$ in photorespiration.

By combining the equations (3) and (4), the equation (5) is given.

$$
\mathrm{Tc}=(2.06 \cdot \mathrm{kc} \cdot \mathrm{Pg}+\mathrm{ETR}) /(3.06 \cdot \mathrm{kc})
$$

where $\mathrm{Pg}$ is a measured value. By substituting Tc given from the equation (5) into the equation (3), the value of $\operatorname{Pr}$ is estimated.

Non-photochemical quenching (NPQ) was calculated from the equation (6). The parameter NPQ is used as an indicator for the ratio of energy dissipation by non-photochemical process.

$$
\mathrm{NPQ}=\left(\mathrm{Fm}-\mathrm{F}^{\prime} \mathrm{m}\right) / \mathrm{F}^{\prime} \mathrm{m}
$$




\section{RESULTS AND DISCUSSION}

\section{Growth analyses}

The climatic data during the cultivation period are shown in Fig. 1. The air temperature of 28 to $30^{\circ} \mathrm{C}$ and the air humidity of 70 to $80 \%$ given here are suitable for growth of both kenaf and napiergrass.

The time course of the total dry weight (W), LA, root weight ratio (R-ratio), PGR and NAR are shown in Fig. $2-A,-B,-C,-D$ and $-E$, respectively. R-ratio is the ratio of the root weight to the total plant weight. The vigorous growth was observed in both species as shown in Fig. 2-A and -B. W and LA of kenaf increased linearly in parallel with those of napiergrass. However, at the early growth stage LA of kenaf was significantly lower than those of napiergrass. This is because kenaf was grown from seeds while napiergrass from shoots. However after one month, $\mathrm{W}$ of kenaf became close to the that of napiergrass. This may show evidence that kenaf has an almost similar potential in production and growth to that of napiergrass.

On the other hand, R-ratio was significantly different between both species. As presented in Fig. 2-C, the R-ratio in kenaf ranged from 15.3 to $18.2 \%$, but in napiergrass, it increased together with $\mathrm{W}$ up to the maximum value of $25.4 \%$. In this comparison, napiergrass is regarded as having a much larger root system than that of kenaf, though napiergrass is known to have rather a poor root system compared to other grass species (Matsuda et al., 1991; Evans, 1993).

The changes in PGR of both species showed a mono-peaked curve with peaks at the $37^{\text {th }}$ and $42^{\text {nd }}$ day in kenaf and napiergrass, respectively (Fig. 2-D). The maximum value of $6.73 \mathrm{~g} \mathrm{plant}^{-1}$ day $^{-1}$ observed in kenaf was a little higher than that of napiergrass, $5.89 \mathrm{~g}$ plant $^{-1}$ day $^{-1}$. However, as a whole, the value of PGR was higher in kenaf than in napiergrass through the cultivation period. In general, $\mathrm{C} 4$-plants are known for a high $\mathrm{CO}_{2}$ assimilation rate and large dry matter productivity. However, in the present study, kenaf (C3-plant) had a higher PGR than that of napiergrass (C4-plant).

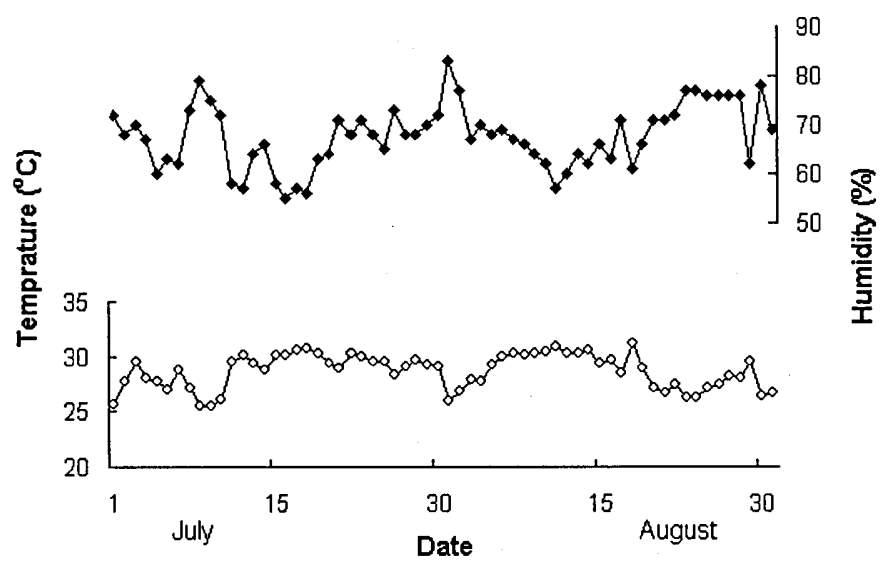

Fig. 1. Climatic condition during the pot cultivation. Average air temperature, $\longrightarrow$; average humidity, $\longrightarrow$ 

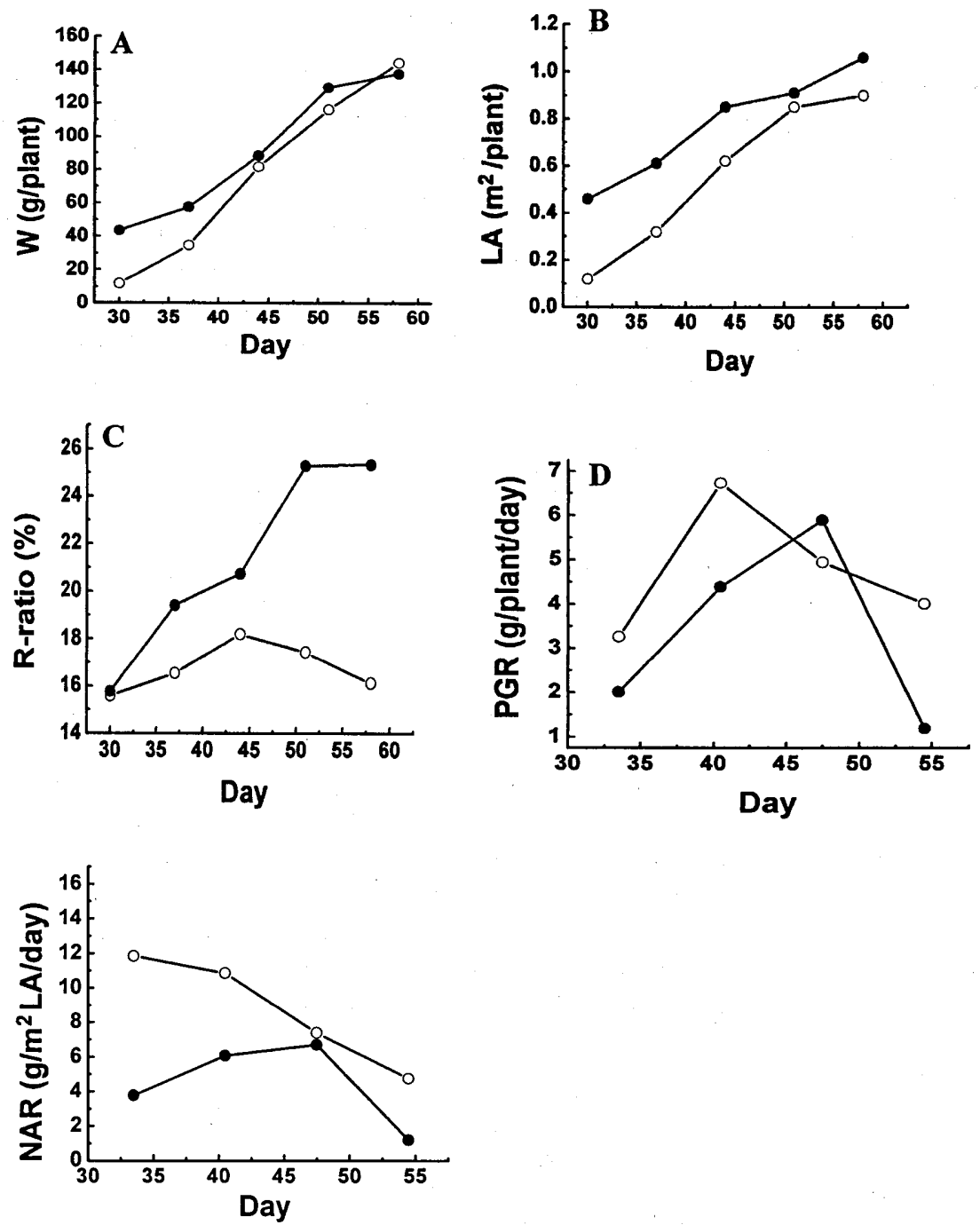

Fig. 2. The time course of total dry weight (W), leaf area (LA), ratio of root weight to total dry weight (R-ratio), plant growth rate (PGR) and net assimilation rate (NAR) in kenaf and napiergrass. Kenaf, $\longrightarrow$ - ; napiergrass, $\longrightarrow-$

NAR was considerably higher in kenaf than in napiergrass as shown in Fig. 2-E. The light penetration efficiency in the plant population is one of the main determinants for NAR (Kubota et al., 1994); however, in this study NAR was calculated for a single plant grown in pots, so the value of NAR is indicated as the average production rate of leaves in a plant. NAR observed in kenaf suggests that the photosynthetic productivity of kenaf was almost similar to that of napiergrass. 


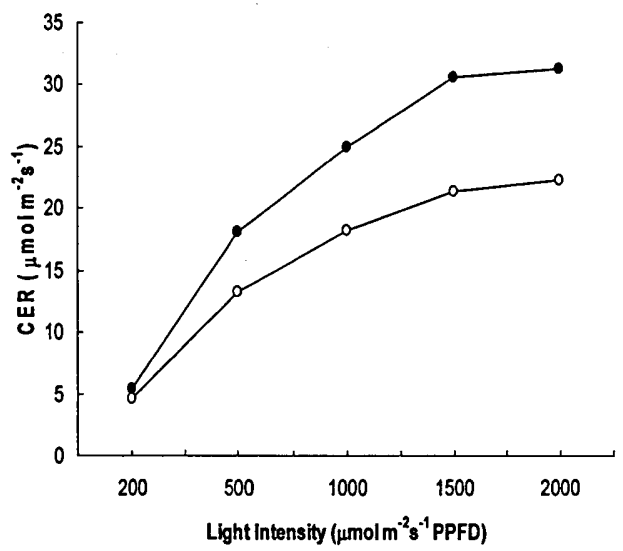

Fig. 3. Light photosynthetic response in kenaf and napiergrass. Kenaf, —— ; napiergrass,

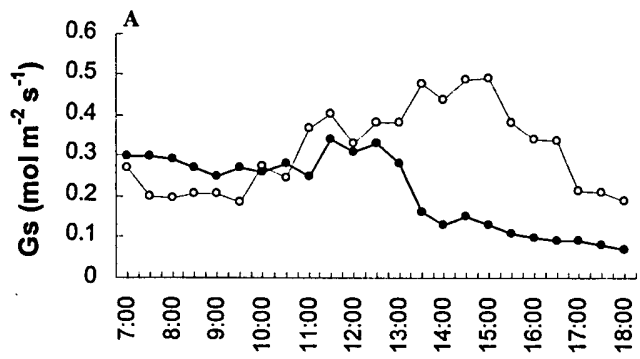

Time

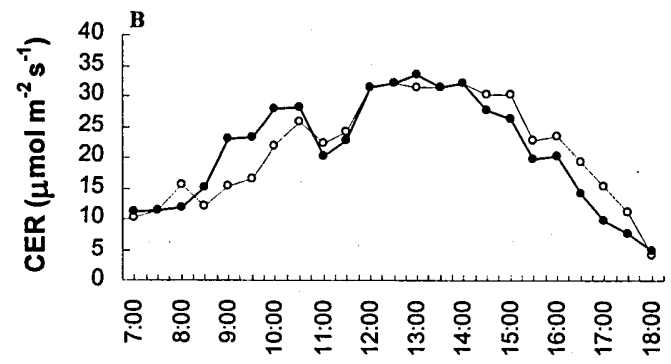

Time

Fig. 4. Diurnal changes in stomatal conductance (Gs) and $\mathrm{CO}_{2}$ exchange rate (CER) in kenaf and napiergrass in sunshiny day. Kenaf, - 
Next, the light-photosynthetic response curves are shown in Fig. 3. CER values of both species increased with an increase in light intensity but that of kenaf was a little lower than napiergrass. However, the higher value of NAR observed in kenaf suggested that kenaf has a beneficial $\mathrm{CO}_{2}$ balance between photosynthesis and respiration in the production system, then the values of $\mathrm{W}$ and $\mathrm{PGR}$ of this species become as large as those of napiergrass.

It is important to understand the light-photosynthetic responses and its relation to stomatal openness, because stomatal action is recognized as one of the main determinants for the photosynthetic rate of a leaf. The diurnal changes of Gs and CER of the both species monitored on a sunshiny day are compared in Fig. 4-A and -B, respectively. A high level of CER was observed from 12:00 to 13:30 in napiergrass and from 12:00 to 15:00 in kenaf. The CER values of napiergrass showed a decreasing tendency in PM. On the other hand, CER of kenaf was lower in the morning, but it reached a higher level by noon and kept a stable value in PM. According to the increase in Gs, the leaf evaporation rate increases. As shown in Fig. 2-C, R-ratio of kenaf is small, but the Gs and CER of this species are high and stable for a long time. This is an interesting phenomenon and a further study is necessary to be tried from the view point of the functional balance between leaf evaporation and root water absorption.

Table 1. Effect of mild and severe- drought treatments on the parameters values of $\mathrm{CO}_{2}$ exchange rate (CER), stomatal conductance (Gs), mesophyll conductance $(\mathrm{Gm})$ and photorespiration (Pr) in kenaf and napiergrass.

\section{A Kenaf}

\begin{tabular}{lcccc}
\hline & $\begin{array}{c}\mathrm{Pn} \\
\mu \mathrm{mol} \mathrm{m}^{-2} \mathrm{~s}^{-1}\end{array}$ & $\begin{array}{c}\mathrm{Gs} \\
\mathrm{mol} \mathrm{m} \mathrm{s}^{-2}\end{array}$ & $\begin{array}{c}\mathrm{Gm} \\
\mathrm{mol} \mathrm{m}^{-2} \mathrm{~s}^{-1}\end{array}$ & $\begin{array}{c}\mathrm{Pr} \\
\mu \mathrm{mol} \mathrm{m}^{-2} \mathrm{~s}^{-1}\end{array}$ \\
\hline Control & $13.67(100)$ & $0.22(100)$ & $0.06(100)$ & $4.21(100)$ \\
Mild drought & $5.85(42.8)$ & $0.09(39.7)$ & $0.02(41.1)$ & $5.14(122.1)$ \\
Recovery & $11.52(84.3)$ & $0.23(105.5)$ & $0.05(80.2)$ & $5.33(126.6)$ \\
Severe drought & $0.51(3.7)$ & $0.02(6.8)$ & $0.002(2.9)$ & $6.31(149.8)$ \\
Recovery & $10.62(77.7)$ & $0.16(72.7)$ & $0.04(71.9)$ & $5.91(140.4)$ \\
\hline
\end{tabular}

B Napiergrass

\begin{tabular}{lcll}
\hline & $\begin{array}{c}\text { Pn } \\
\mu \mathrm{mol} \mathrm{m}^{-2} \mathrm{~s}^{-1}\end{array}$ & $\begin{array}{c}\mathrm{Gs} \\
\mathrm{mol} \mathrm{m}^{-2} \mathrm{~s}^{-1}\end{array}$ & $\begin{array}{c}\mathrm{Gm} \\
\mathrm{mol} \mathrm{m}^{-2} \mathrm{~s}^{-1}\end{array}$ \\
\hline Control & $18.83(100)$ & $0.16(100)$ & $0.13(100)$ \\
Mild drought & $3.01(16.0)$ & $0.05(30.1)$ & $0.02(13.9)$ \\
Recovery & $16.4(87.1)$ & $0.16(97.4)$ & $0.10(77.7)$ \\
Severe drought & $0.99(5.3)$ & $0.01(7.6)$ & $0.01(4.1)$ \\
Recovery & $10.82(57.5)$ & $0.12(71.7)$ & $0.05(41.6)$ \\
\hline
\end{tabular}




\section{Specific difference in the photosynthetic response to drought conditions}

The drought treatments were imposed on plants 30 days old in pots. The treatments were carried out during the most vigorous growth period just before PGR peaked in both species (Fig. 2-D).

The parameters related to leaf gas exchange in both species grown under drought conditions are shown in Table 1-A and -B. The mild and severe drought treatments were imposed to plants by restricting water supply, by which the soil water potential levels finally decreased to -1.33 and $-2.51 \mathrm{MPa}$, respectively.

The value of CER in control plant measured at $500 \mu \mathrm{molm}^{-2} \mathrm{~s}^{-1}$ PPFD (Table 1-A and -B) was larger for napiergrass $\left(18.83 \mu \mathrm{molm}^{-2} \mathrm{~s}^{-1}\right)$ than for kenaf $\left(13.67 \mu \mathrm{molm}^{-2} \mathrm{~s}^{-1}\right)$. By imposing the severe drought treatment, CER of both species was greatly depressed to several percent levels of the control values. On the other hand, in the mild drought treatment, a significant specific-difference was found: CER decreased to $16.0 \%$ of the control in napiergrass, while it kept at $42.8 \%$ in kenaf.

The responses of Gs and Gm to the droughts showed a similar tendency to that of CER. Under the severe drought both parameter values decreased close to zero in both species. However, under the mild drought condition Gs and $\mathrm{Gm}$ of kenaf held about $40 \%$ of the control values; while in napiergrass Gs and Gm decreased to $30.1 \%$ and $13.9 \%$ of the control, respectively. This may predict that CER of napiergrass was more strongly related with $\mathrm{Gm}$ than Gs.

By re-watering, CER of kenaf subjected to the mild and severe droughts returned up to 84.3 and $77.7 \%$ of the control, respectively (Table $1-\mathrm{A}$ and $-\mathrm{B}$ ). On the other hand, the recovery level of CER in a mildly stressed napiergrass was $87.1 \%$, and that of a severely stressed one was less than $60 \%$. Napiergrass is likely inferior in photosynthetic recovery to kenaf in this experiment.

Both Gs and Gm also increased by re-watering (Table 1-A and -B). Gs of the mild drought-experienced plants returned to $100 \%$ or more in both species, but that of plants placed in the severe drought ranged from 71.7 to $72.7 \%$ in the recovery treatments. The recovery ratio of $\mathrm{Gm}$ was less than that of Gs, especially the $\mathrm{Gm}$ recovery ratio in napiergrass subjected to the severe drought was low, staying at $41.6 \%$. Like this, the drought stress had a significant effect on Gs and Gm, and in napiergrass, Gm was more severely damaged by droughts.

Photorespiration is regarded as one of the main functions reflecting the difference between C3- and C4-plant in photosynthesis (Raghavendra., 1998; Edward and Walker, 1983). Pr, as an in situ value, of kenaf was calculated from the equations (3), (4) and (5). The Pr value of kenaf increased by 22.1 and $49.8 \%$ in the mild and severe drought treatments, respectively. The energy used to release $1 \mathrm{~mol}$ of $\mathrm{CO}_{2}$ by photorespiration was more than two times of that used to fix $1 \mathrm{~mol}$ of $\mathrm{CO}_{2}$ by assimilation (Oliver, 1994); then the existence of photorespiratory function is considerably effective in reducing the excessively produced energy in leaves grown under drought conditions, by which the photosynthetic system can be protected from the photo-hazard.

In general, C4-plants are mentioned to show no photorespiration under the normal growth condition, but Sato et al., (2004) reported that photorespiratory function was activated in C4-plants under drought conditions. Guineagrass (Panicum maximum Jacq., PEP-CK subtype of C4 plant) and common millet (Panicum miliaceum L., NAD-ME 
subtype) showed a higher photorespiration and a stronger drought tolerance than corn (Zea mays L., NADP-ME subtype). It is interesting to investigate the existence or activation of photorespiration in napiergrass (NADP-ME subtype) grown under drought conditions.

The situation of electron transport in a leaf is also an important factor related to both prevention and recovery of photosynthetic functions. Fv/Fm, Фe, ETR and NPQ in kenaf and napiergrass are shown in Table $2-\mathrm{A}$ and $\mathrm{B}$, respectively.

The Fv/Fm parameter is used as an indicator for the functional capacity of PSII. Under the less-stressed growth condition, $\mathrm{Fv} / \mathrm{Fm}$ has a value of about 0.8 in general. As shown in Table 2, this parameter was closed to 0.8 in the control plant of kenaf and napiergrass. Genty et al. (1987) mentioned that Fv/Fm was not changed even by severe droughts. But $\mathrm{Fv} / \mathrm{Fm}$ shown in Table 2 decreased in the drought treatments, and the decrease ratio was a little larger in napiergrass than in kenaf. By re-watering, these values almost completely returned to the control level. Like this, the functional capacity of PSII is not so strongly damaged by droughts. This phenomenon considerably differs from that observed on gas exchange parameters shown in Table 1.

The values of $\Phi$ e and ETR reduced in the drought treatments. The reduction ratio in kenaf was only $20.2 \%$ under the severe drought; while that in napiergrass was large, showing about $40 \%$. In kenaf, $\Phi$ e and ETR returned to the control level by re-watering,

Table 2. Maximam quantum yield ( $\mathrm{Fv} / \mathrm{Fm}$ ), PSII quantum yield $(\Phi \mathrm{e})$, electron transport (ETR) and non-photochemical quenching (NPQ) of kenaf (A) and napiergrass (B) under two drought levels condition and recovery.

A Kenaf

\begin{tabular}{lcccc}
\hline & Fv/Fm & \multicolumn{1}{c}{$\Phi \mathrm{e}$} & $\begin{array}{c}\text { ETR } \\
\mu \mathrm{mol} \mathrm{m}^{-2} \mathrm{~s}^{-1}\end{array}$ & NPQ \\
\hline Control & $0.81(100)$ & $0.57(100)$ & $113.20(100)$ & $0.98(100)$ \\
Mild drought & $0.76(95.0)$ & $0.45(78.8)$ & $89.24(78.8)$ & $1.48(151.0)$ \\
Recovery & $0.78(96.6)$ & $0.62(110.3)$ & $124.81(110.3)$ & $0.83(84.7)$ \\
Severe drought & $0.80(99.1)$ & $0.45(79.8)$ & $90.34(79.8)$ & $1.48(151.0)$ \\
Recovery & $0.79(98.0)$ & $0.61(107.5)$ & $121.67(107.5)$ & $0.87(88.8)$ \\
\hline
\end{tabular}

B Napiergrass

\begin{tabular}{lllll}
\hline & Fv/Fm & $\Phi \mathrm{e}$ & $\begin{array}{c}\mathrm{ETR} \\
\mu \mathrm{mol} \mathrm{m}^{-2} \mathrm{~s}^{-1}\end{array}$ & $\mathrm{NPQ}$ \\
\hline Control & $0.76(100)$ & $0.48(100)$ & $96.00(100)$ & $1.34(100)$ \\
Mild drought & $0.69(91.3)$ & $0.33(68.8)$ & $66.00(68.8)$ & $1.56(116.4)$ \\
Recovery & $0.77(101.7)$ & $0.42(88.2)$ & $84.69(88.2)$ & $1.50(111.9)$ \\
Severe drought & $0.70(92.2)$ & $0.20(41.7)$ & $10.00(41.7)$ & $1.56(116.4)$ \\
Recovery & $0.75(99.1)$ & $0.40(84.1)$ & $80.76(84.1)$ & $1.48(110.5)$ \\
\hline
\end{tabular}


but the recovery ratios of napiergrass were significantly low. It has been frequently reported that $\mathrm{C4}$-plants such as napiergrass are more tolerable against severe droughts, but in our study, kenaf has a far better recovery in the photosystem function judging from $\mathrm{Fv} / \mathrm{Fm}$ value. In addition, it may be suggested that kenaf effectively prevents photo-damages by more sensitively changing NPQ with the environmental conditions. The drought treatments significantly increased ETR in kenaf. This phenomenon is attributable to the high photorespiration rate in this species (Table 1), by which the excessive energy produced in a strong sun light and water deficits is diffused, and the photosynthetic apparatuses are protected.

As mentioned above, the specific feature in photosynthetic response of kenaf is characterized by the following two points: one is the sustaining of a high CER under the normal growth condition and the other is the increase in photorespiration rate under the drought conditions. From these points we suggest that kenaf is able to perform a high production and drought tolerance comparable to those observed in C4-plants like napiergrass.

\section{REFERENCES}

Alexopoulou, E., M. Christou, M. Mardikis and A. Chatziathanassiou 2000 Growth and yields of kenaf varietes in central Greece. Industrial Crop and Production, 11: 163-172

Chaves, M. M. 1991 Effect of water deficit on carbon assimilation. J. Exp. Bot., 42: 1-16

Cornic, C. and A. Massacci 1996 Leaf photosynthesis under drought stress. In "Photosynthesis and Environment" ed. by N. R. Baker. Kluwer Academic Publ., Dordrecht, Boston, London, pp. 347-366

Cornic, G. 2000 Drought tress inhibits photosynthesis by decreasing stomatal aperture-not by effecting ATP synthesis. Trends Plant. Sci, , 5: 187-188

Edwards, G. and D. A. Walker C3, C4: mechanism, and cellular and environmental regulation of photosynthesis. Blackwell Scientific Publications, pp. 368-409

Evans, L. T. 1993 Crop evolution, adaptation and yield. Cambridge University Press, pp. 251-253

Francois, L. E., T. J. Donovan and E. V. Maas 1992 Yield, vegetative growth and fiber length of kenaf grown on saline soil. Agron. J., 84: 592-598

Genty B., J. M. Briantais and J. B. Viera da Silva 1987 Effect of drought on primary photosynthetic processes of cotton leaves. Plant Physiology, 143: $642-650$

Kubota, F., Y. Matsuda, W. Agata and K. Nada 1994 The relationship between canopy structure and high productivity in napiergrass, Pennisetum purpureum Schumach. Field Crops Research, 38: 105-110

Lam, T. B. T., H. Keko and I. Kenji 2003 Structural characteristics of cell walls of kenaf (Hibicus cannabinus L.) and fixation of carbon dioxide. J. Wood Sci., 49: 255-261

Matsuda, Y., F. Kubota, A. Waichi and I. Koji 1991 Analytical study on hight productivity in napiergrass (Pennesetum purpureum Schumach.) 1. Comparision of the characterstics of dry matter production between napiergrass and corn plants. J. Japan. Grassl. Sci., 37: 150-156

Medrano, H., J. M. Escalona, J. Bota and J. Flexas 2002 Regulation of photosynthesis in C3 plants in response to progressive drought: Stomatal conductance as reference parameter. Annals of Botany, 89: 895-905

Nada, K., F. Kubota, W. Agata. and F. Matsuda. 1994 Characteristic of dry matter production and photosynthesis in napiergrass and maize. Sci. Bull. Fac. Agr., Kyushu Univ., 48: 163-169

Nagasuga, K. 2003 Effect of growth light intensity on the water transport regulation and leaf photosynthesis in napiergrass (Pennisetum purpureum Schumach). Bull. Inst. Trop. Arg. Kyushu Univ., 26: $53-58$

Ogbonnaya, C. I., M. C. Mwalozie, H. Roy-Macauley and D. J. M. Annerose 1998 Growth and water relation of Kenaf (Hibicus cannabinus L.) under water deficit on sandy soil. Industrial Crop and Production, 8: 65-76 
Oliver, D. J. 1994 The glycine decarboxylase complex from plant mitochondria. Ann. Review of Plant Physiol. and Plant Mol. Biol., 45: 323-337

Osmond, C. B. 1994 What is photoinhibition? Some insights from comparision of shade and sun plants. In "Photoinhibition of photosynthesis from molecular mechanism to the filed" ed. by N. R Bake and J. R Bowyer. Scientific Publishers Lancaster. pp. 1-24

Raghavendra, A. S. 1998 Photorespiration and $\mathrm{C}_{2}$ cycle. In "Photosynthesis. A Comprehensive Treatise", ed. by D. J. Oliver. Cambridge University Press. pp. 173-182

Sato, A. and F. Kubota 2004 Specific difference in photorespiration activity in C4 subtype plants and its relationship with drought tolerance of leaf photosynthesis. J. Fac. Agr., Kyushu Univ., 49: 25-32

Watkins, J. M. 1951 Effect of frequency and height of cutting on the yiled, stand and protein content of some forages in EL Salvador. Agron. J., 43: 291-296

Wingler, A., W. P. Quick, R. A. Bungard, K. J. Bailey, P. J. Jea and R. C. Leegood 1999 The role of photorespiration during drought stress: an analysis utilizing barley mutants with reduced activities of photorespiratory enzymes. Plant, Cell and Environ., 22: 361-373 